\section{Aortic impairment in giant-cell artheritis and life-threatening risks}

\section{Description}

72 years old female, totally independent, with previous diagnosis of temporal arteritis $^{1}$ and major cardiac surgery (aortic mechanical valve substitution and dacron graft of the ascending aorta), under treatment with prednisolone and warfarine, was admitted to the Internal Medicine ward due to an hypertensive crisis with chest pain.

Excluded an acute coronary syndrome, the patient has undergone a pulmonary CT scan which revealed a marginal thrombus, without entering flap, just below the left subclavian artery, suggestive of an atheromatous ulceration. ${ }^{2}$ Due to her previous comorbidities, she was also submitted to a positron emission tomography which suggested inflammatory impairment of the ascending, arch and descending aorta (figure 1), as well as the left carotid artery (figure 2).

Standard prednisolone and high doses of statin were implemented and the patient kept her normal life activities.

Four months later, she was readmitted with fever, myalgia and erratic behaviour. Leaded by an abnormal cardiac auscultation, transthoracic echocardiogram revealed signs of infective endocarditis related to a severe paraprosthesis leak complicated with abscess. Becoming less capable, another major cardiac surgery was weighted, but because the unfavourable risk/ benefit ratio only antibiotherapy (aminoglycoside) was implemented.

The patient progressed to a stage of total dependency, leading to the necessity of a permanent nursing facility and, less than a year from her first admission, developed two severe infection, culminating into a fatal nosocomial pneumonia.

Previous information from her cardiac surgery were not available, but one can relate giant-cell arteritis with and aortic aneurism. ${ }^{3}$

\section{Learning points}

1. Giant cell arteritis is not limited to the temporal arteries

2. Because many differential diagnosis are limited to histopathologic analysis, a high index of clinical suspicion is mandatory

3. Corticotherapy is imperative, but, regarding risks and benefits, shouldn't be implemented without a full assessment

\section{References}

1. Bhaskar Dasgupta on behalf of the Giant Cell Arteritus Guideline Development Group. Diagnosis and management of giant cell arteritis - Concise guidance to good practice series. Royal College of Physicians 2010

2. Nesher G. Autoimmune Aspects of Giant Cell Arteritis. IMAJ 2014; 16: 454-455.

3. Pak M, Ito S, Tekda M, Watanabe N, Sato H, Ito S et al. A Case of Ascending Aortic Dissection and Rupture Caused by Giant Cell Arteritis. Int Heart J 2014; 55: 555-559.

\section{Diagnóstico: Aortic impairment in giant-cell artheritis}

\section{Bernardo Cunha, Sónia Moreira}

Centro Hospitalar e Universitário de Coimbra - Medicina Interna

Correspondencia: joaobernardocf@gmail.com

Como citar este artículo: Cunha B, Moreira $S$

Aortic impairment in giant-cell artheritis and life-threatening risks. Galicia Clin 2015; 76 (4): 181

Recibido: 10/08/2015; Aceptado: 16/09/2015
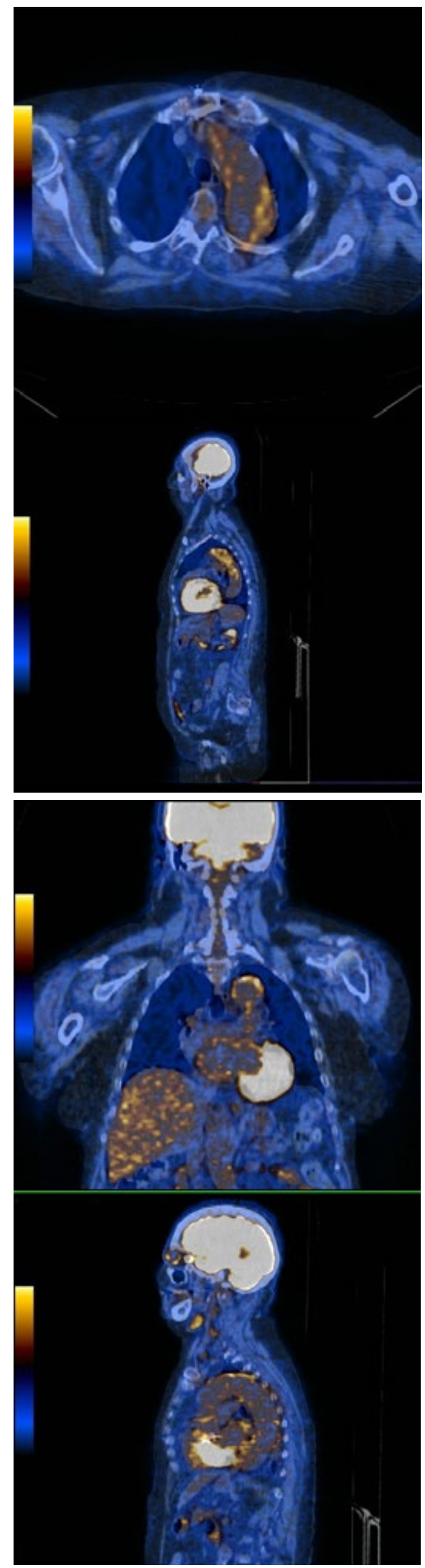